\title{
Comment:
}

\section{The State and Civil Society in Pakistan}

\section{A. Rehman}

The state of Pakistan appears to have embarked upon a process of transforming itself. It faces a host of grave socio-political and economic issues which manifestly do not yield to the traditional style of governance. It has also realised that its decayed and outdated administrative system cannot enable it to discharge its social sector obligations even on the limited scale the population has become used to. Thus, on the one hand, it is availing of the opportunities afforded by the rhetoric of globalisation and market economy, and withdrawing from whatever social responsibilities to the people it hitherto recognised - in the areas of education, health, employment, communications, public utilities, etc. On the other hand, it is trying to reinforce its coercive powers through increased reliance on majoritarianism, authoritarian approaches to issues generally reserved for democratic decision-making, and short-circuiting of judicial processes.

This developing phenomenon merits examination from several angles. One important aspect, with which we are concerned in the present essay, concerns the future relationship between the state and the civil society. It is already obvious that the state is gradually abandoning the urban modernists who uphold the universal norm of democracy, rule of law and fundamental rights, which were never totally repudiated in the past. At the same time efforts are being made to redefine the state's ideology once again and to mobilise conservative religious forces to enforce it even at the cost of law. The process is bound not only to drastically alter the democratic structure of the state, it will also reshape its relationship with the individual and with many elements of civil society.

The relationship between civil society and the state in Pakistan has always been a problematic issue. The concept of democracy, as derived from the theory of social contract, did not develop in Pakistan as a result of the changing equation between the rulers and subjects. Pakistan is a state brought into being under a compact its inhabitants had with their colonial rulers and who are supposed to have laid down a framework for state-people is not subject to their mandate. The present constitution does not represent the will of the people, it represents a political contraption devised by a single individual who enjoyed no sanction except that of brute force. That he accommodated in his scheme some features of a consensus document (the 1973 Constitution) does not materially affect the character of the basic law governing the state. This 
constitution has laid the foundation of confrontation between the state and the people. It leaves quite a few issues of individual's rights, at least of such sections of the population as women and minorities, ethnic communities' aspirations, and unit - federation relationship unanswered and liable to be misconstrued.

By and large Pakistan's civil society has operated within the confines determined by the state. However, the people have had to intervene directly on several occasions to correct its political course. They has given the state's founding fathers a mandate to establish a federation of autonomous units to be governed in accordance with the parliamentary system. They never got what they had asked for. The provincial entities in the western wing were obliterated in 1955. In 1958 the popular mandate was overruled by a martial law administrator who propounded his own theory of controlled democracy. His adventures in the state's transformation were suffered for over a decade and finally rejected. But the people did not get what they had fought for. Another praetorian regime took over. It conceded some of the popular demands but resisted some others with such obduracy that the resultant strife culminated in the state's dismemberment. A new beginning was made to manage the state in accordance with the wishes of the people but before long the state and the people found themselves in their adversarial roles and another military adventurer rose to establish his personal rule. The people rose against him, too. Instead of conceding what the people demanded he foisted on them a political dhancha (framework) of his own contrivance. Since his death a decade ago the people have elected their representatives four times. During this period some changes have indeed been made in Ziaul Haq's siyasi dhancha, but its essential features have survived and no attempt to erase them is in sight. And now we are witnessing the state's attempts to put only one element of the civil society the militants mobilised under religious banners - in the driving seat without any regard to the interests and views of the rest of the civil society.

What do we mean by civil society? It is difficult to apply this term to a mass of people who occasionally set themselves a single-point task. They may come together to secure freedom from colonial rule, to replace dictatorship with representative government, or to overthrow an oppressive socio-economic order. But anti-colonial movements, struggles for restoration of democracy, or even revolutions are in the nature of short-term popular fronts. They may succeed or fail or they may partly achieve their objectives, their impact is transitional whereas civil society's role presupposes a degree of permanence and dynamism.

Unfortunately the expression "civil society" has been bandied around in Pakistan somewhat carelessly. We have tended to assume any order in 
which the military does not openly assume sovereign powers to be not only civilian but also civil, though it may be neither. Off and on, the slogan of civil society's supremacy over military establishment is raised. But you can have a non-military state that is in confrontation with the civil society, that does not acknowledge it.

It could be argued that elements of civil society did contribute to the upheavals referred to above. Politicians, workers, academics, lawyers, journalists contributed to the movement against the Ayub regime or that Mr. Bhutto derived his political slogans from the thesis the radicalised elements of civil society had offered. Gen. Zia too was forced to climb down from the pedestal of a divinely ordained patriarch by the jolts he received from civil society's groups. While all this may be true, it does not give us the picture of a civil society that can productively interact with the state or can mediate between it and the people.

In order to appreciate the essential features of a dynamic civil society we have to take a look at the theory of the democratic state. Such a state has its jurisdiction demarcated by the people. It has no authority to intervene in areas the people have not placed under its jurisdiction, areas in which the people deem themselves free to pursue their interests, individually or in groups. These areas can cover a wide range -- from basic individual rights, to social, cultural and economic rights of communities and groups. But states are by definition expansionist. They tend to over-step their jurisdiction and interfere in matters outside their domain. It is to prevent this, to oblige the state to operate within its legitimate confines, that civil society develops institutional safeguards. In an ideal democracy the state would not only acknowledge the institutions of civil society but also develop an arrangement whereby the state and civil society play complementary roles, thereby reducing the coercive attributes of the state and making governance subject to participatory principles. The problem of civil society's neglect does not arise acutely in mature democracies because there civil society has developed alongside the emergence of democratic institutions. Indeed, institutions of rule have developed under pressure from civil society.

No such arrangement is possible in a totalitarian state. In the models we have seen over the past five decades the functions of civil society have often been assumed by the state directly or indirectly. In our own history we have seen how authoritarian rulers have tried to usurp the functions of civil society. Let us examine the situation of some of the more prominent elements of civil society that could be expected to throw up countervailing forces -- landlords, farmers, business people, industrial workers, mediapersons, lawyers, teachers, writers, professional groups such as doctors, 
engineers, architects, women's groups, youth, and NGOs. Our authoritarian rulers have sought to pursue what Gramsci identifies as hegemonic interests in two ways. First, by making laws that restrict these groups' functioning and, secondly, by imposing state nominees on their associations. The one group that has escaped their attention is that of landlords and that for the obvious reason of their hold over state power. The chambers of commerce and industry are at the sufferance of the Ministry of Commerce vide the law on trade bodies. When Ayub Khan deprived teachers of their rights as an important group in civil society by promulgating University Ordinances and degrading academics to the level of state employees, or when he created the National Press Trust or the Writers' Guild to tell the Press or the writers what their interests were, he was not far from following Mussolini's text on transforming civil society into an appendage of the state system.

Pakistani rulers' desire to control civil society's platforms is insatiable. When government changes the heads of Bar council, media organisations, cultural outfits, science and literary academics also change. But these changes do not alter the relationship between the state and these organisations. The latter continue as agents posted to force the civil society to conform to the interests and policies of the state.

Before we note the extent to which our state has robbed the civil society of the possibilities of developing an institutional framework for interaction, it may be necessary to point out the flaws in the political structure itself. The fact of the matter is that Authority has nearly always been reluctant to accept one of the cardinal principles of constitutionalism - that of division of power. The executive has consistently declined to treat the legislature and the judiciary as co-equal organs of the state. The biggest casualty has been the legislature. It has become subservient to the executive, which may mean a small coterie or just an individual.

A democratic legislature is supposed to function as a bridge between the state and civil society. In countries that have written constitutions a legislature has to be conscious of the constitutional limits to its authority. If it adheres to the spirit of representative governance it cannot ignore its duty to respect public opinion. A responsible legislature therefore continually seeks guidance from the people or civil society institutions before making laws or framing policies which affect civil society as a whole or some parts of it. We had begun to recognise this imperative of representative rule in the colonial period when the legislature started developing safeguards against the executive's initiatives. What did the system of standing and select committees introduced in our part of the world much before independence mean? It meant the need to get an executive prescription examined by elements outside the government to determine whether it really conformed 
to the public good as claimed. And there could be occasions when it was found necessary to seek a bill's circulation to elicit the views of the public. Does it not strike as odd that the parliaments we have had for several decades have no time for debate and do not elicit public views on any measure? One would present the discontinuation of the system of referring legislative proposals to the public as legislature's surrender to the executive at the cost of its obligations to civil society.

The setbacks the people of Pakistan have had in their quest for a democratic dispensation, and especially the failure to break the authoritarian mould, have prevented the emergence of active institutions of civil society. At the horizontal level, the unresolved unit-federation confrontation has precluded the rise of civil society's forums on a national scale. Attempts to form national organisations of farmers, workers, teachers, students women, youth et al have more often than not failed and where some notional unity of provincial interests has occasionally been secured, their effectiveness is not visible. Besides, more decisive than the institutional underpinnings of authoritarianism is the culture it fosters. Civil society cannot interact with state institutions if the latter do not accept the principle of interaction itself.

The situation at present is that there are elements in Pakistan that are conscious of their right to interact with the state but there is no formal or informal mechanism for such interaction nor any mutually accepted ground rules. The state takes notice only when a section of civil society displays capacity to disrupt normal life. Today the state's topmost priority seems to be its desire to be on the right side of the religious lobby. The only other elements of civil society that it acknowledges are landlords and businessmen. The landlords do not have to confront the state in the open. They can have their way in legislatures and through their hold over the bureaucracy. Witness the exclusion of land reform from the national agenda and the imbroglio that has been made of the agricultural tax proposal. The businessmen are recognised by virtue of their ability to bring the shutters down. Witness the unending haggle over sales tax. When CBR inspectors raid a business house to catch tax evades, nothing happens to the culprits, the state functionaries are reprimanded. All other elements of civil society are treated with contempt. All the teachers of Pakistan cannot persuade the state to adopt a modern, rational curricula. The entire lawyer community may cry itself hoarse against bad laws, the state will not listen. Women organisations have been agitating against Hudood laws and the state stubbornly refuses to budge an inch. Take the latest events in Karachi. Had the state paid heed to civil society's initiatives for a settlement the present ugly turf war might have been avoided. 
Statecraft based on the greatest good of the greatest number demands that the state must accept civil society's role in raising the people to a higher stage of moral and material satisfaction. This demands the creation of an environment in which all elements of civil society can be peacefully accommodated. It demands renunciation of force, even of laws bearing the stamp of arbitrariness, and a shift from majoritarian rule to participatory democracy. Unfortunately, the state of Pakistan now seems to be moving in the opposite direction.

The consequences of this drift are not difficult to imagine. Exclusive reliance on denominational elements of society can be extremely dangerous in a situation where these elements deny the very right to existence to nearly all other components of the civil society - the provincial entities, the ethnic communities, the modern academics, the scientists, woman activists, human right defenders, et al. This will not only complete the process of civil society's exclusion from public affairs, it could breed further strife among its different elements. 